\title{
The Use of the Test for Oral Muscular Coordination Ability to Increase the Level of Adaptive Capacity of Oral Cavity Organs to Prosthodontic Treatment of Patients with Completely Absent Dentition
}

\author{
Volodymyr Sarapuk
}

\begin{abstract}
Increase in the level of adaptive capacity of oral cavity organs to the prosthodontic treatment of patients with completely absent dentition is one of the urgent problems of modern dentistry. In order to increase the level of adaptability to complete removable laminar dentures, a set of standard samples according to $\mathrm{H}$. Landt was used to test the ability for precise coordination of masticatory muscles - the MA-test (Muscular-Ability) as a means of a group of muscles stimulation providing precise coordination of masticatory muscles. This adaptation process was called MA-stimulation. The level of adaptive capacity of the oral cavity organs was studied using oral stereognosis. The criteria for oral stereognosis assessment included the average time of one sample determination (sec) and the correctness of the samples determination (\%). In order to achieve the objective, we conducted a study of tactile sensitivity in the oral cavity using oral stereognosis in 90 patients with completely absent dentition who applied for the prosthodontic retreatment. The patients' age ranged from 45 to 89 years. The patients were divided into two groups. Group I included 30 patients who underwent the prosthodontic treatment without preliminary MA-stimulation. Group II included 60 patients who underwent MA-stimulation for 14 days before the prosthodontic treatment.

According to the results of oral stereognosis in Group II of patients, the average time of one sample determination after fourteen days of MA-stimulation decreased by $24.5 \%(p<0.05)$ and the index of correctness of the samples determination increased by $32.0 \%(p<0.001)$; the average time of one sample determination decreased by another $19.3 \%$ in 1 month after the prosthodontic treatment, and it decreased by $17.4 \%(p<0.05)$ in 3 months after the prosthodontic treatment; the index of the correctness of the samples determination increased by $17.5 \%$ $(p<0.001)$ and $10.5 \%(p<0.01)$ respectively in 1 and 3 months after the prosthodontic treatment.

Oral stereognosis indices changed significantly only in 1 month after the prosthodontic treatment in Group I of patients who did not undergo MA-stimulation: the average time of one sample determination decreased only by $14.7 \%(p<0.05)$, and the index of correctness of the samples determination increased only by $24.5(p<0.05)$.

According to the results of the research, MA-stimulation is advisable to be included into the prosthodontic treatment of the patients with completely absent dentition as a means of increasing the adaptive capacity of the oral organs.
\end{abstract}

\section{Keywords}

adaptation; completely absent dentition; complete removable laminar dentures; oral stereognosis; precise coordination of masticatory muscles

Ivano-Frankivsk National Medical University, Ivano-Frankivsk, Ukraine

Corresponding author: volodia.sk@gmail.com 
Problem statement and analysis of the latest research

One of the problems of prosthodontic treatment of patients with completely absent dentition is the adaptation to complete removable laminar dentures (CRLD) $[4,7,10]$. This problem becomes more and more important with age and is especially relevant in older age [1]. According to Professor R. Marxkors, the most characteristic signs of biological aging include decrease in the ability to study and inability to adjust to changes including objective external conditions. Masticatory muscles are extremely sensitive to the form of CRLD resulting in the main load falling on the muscle groups located along its external boundary. If CRLD is inserted into such system without preliminary preparation, the system will apparently perceive it as a completely foreign body. Herewith, the period of adaptation to CRLD may last long [7].

In 1975, H. Landt proposed a test for oral muscular coordination ability - the MA-test (Muscular Ability) [16]. The test was proposed to check the human ability to perform actions or movements requiring a certain level of precise coordination of different groups of masticatory muscles. In order to determine the ability of precise coordination of masticatory muscles, the patients were requested to collect consistently several standard samples consisting of two parts with the help of masticatory muscles. The time spent on the sample collection and the percentage of errors was considered as the criteria for evaluation [7]. According to the results of the MA-test, the duration of the collection and the percentage of errors in the elderly and people of senile age were significantly higher; and the ability to study was lower than that in young people $[3,8,16,17]$.

The objective of the research was to use a set of standard samples for MA-test as a means of stimulation of a muscle group providing a precise coordination of masticatory muscles in patients with completely absent dentition during the prosthodontic treatment. The objective was also to study the increase in the level of adaptive capacity of oral cavity organs after the stimulation of the muscle group providing a precise coordination of masticatory muscles in patients with completely absent dentition.

\section{Materials and Methods}

In order to achieve the objective, we conducted a study of tactile sensitivity in the oral cavity using oral stereognosis in 90 patients with completely absent dentition who applied for the prosthodontic retreatment. The patients' age ranged from 45 to 89 years. Two clinical groups were formed from this category of patients by randomized method. Group I (clinical comparison) included 30 patients for whom prosthodontic treatment included the manufacture and use of CRLD without preliminary stimulation of the muscles group providing the precise coordination of masticatory muscles. Group II (the main group) included 60 patients who underwent the stimulation of the muscles group providing the precise coordination of masticatory muscles before the prosthodontic treatment with the manufacture and use of CRLD. We used the term MAstimulation in our work to refer to the process of "stimulation of a group of muscles providing precise coordination of masticatory muscles". Oral stereognosis in the main group was studied before the prosthodontic treatment; after the conduction of MA-stimulation (within 14 days) - before CRLD retention; 1 and 3 months after the completion of prosthodontic treatment.

Oral stereognosis in the group of clinical comparison was studied before the prosthodontic treatment; in 14 days (before CRLD retention); in 1 and 3 months after the completion of the prosthodontic treatment. The control group consisted of 30 individuals without denture defects and with sanitated oral cavity who underwent the study of oral stereognosis in one visit.

The sets of standard samples according to $\mathrm{H}$. Landt (Fig. 1, Fig. 2) consisting of four square figures in the size of $15 \mathrm{~mm} \times 15 \mathrm{~mm}$ and the thickness of $4 \mathrm{~mm}$ were made of "Sinma M" plastic for MAstimulation in the dental laboratory of the Department of Stomatology of Postgraduate Study Faculty at the State Higher Educational Institution "Ivano- 
The Use of the Test for Oral Muscular Coordination Ability to Increase the Level of Adaptive Capacity of Oral Cavity Organs to Prosthodontic Treatment of Patients with Completely Absent

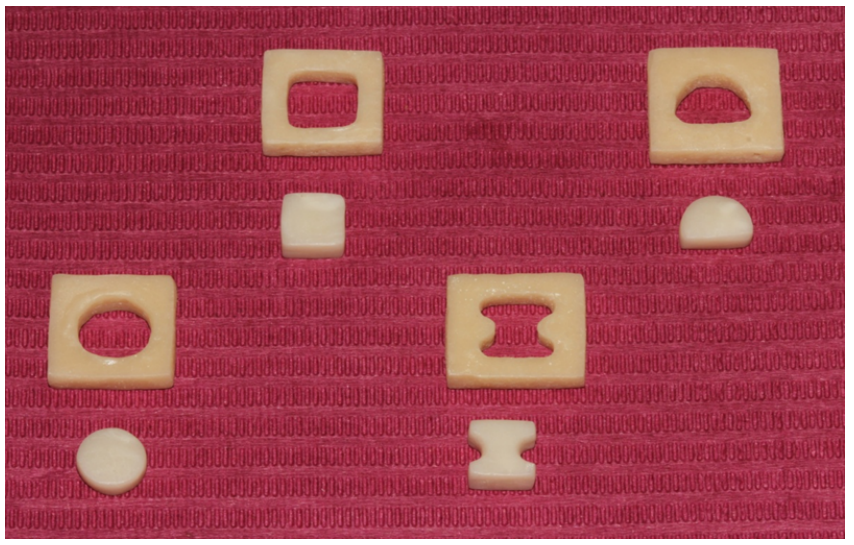

Figure 1. A set of standard samples for MA-stimulation in the disassembled state.

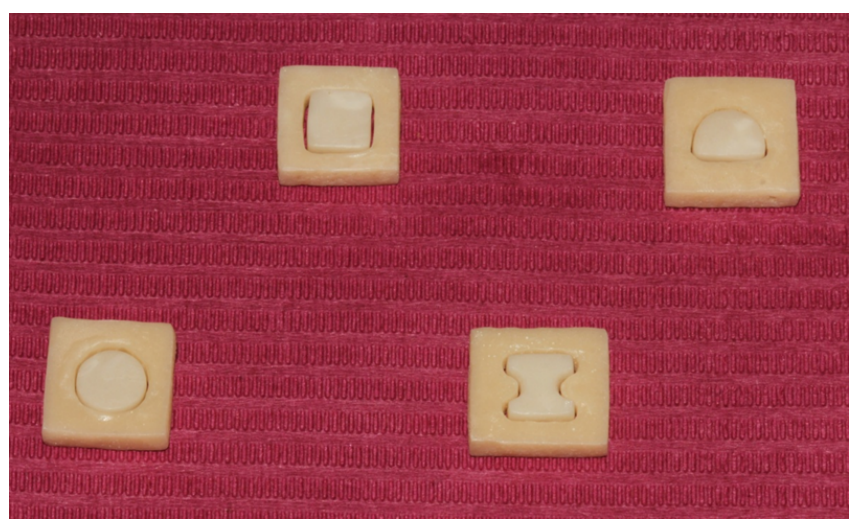

Figure 2. A set of standard samples for MA-stimulation in the assembled state.

Frankivsk National Medical University". Each of the four figures consisted of two parts (external and internal) easily fused together. The sizes of the internal parts depended on the configuration, but did not exceed $4 \mathrm{~mm} \times 4 \mathrm{~mm}$ and thickness of $4 \mathrm{~mm}$ $[7,16]$.

The method of MA-stimulation was conducted in the following way: two details of one disassembled figure were put on the patient's tongue using tweezers and the patient was asked to collect the figure (to combine internal and external details) with the help of masticatory muscles. Having collected the figure, the patient spat it into a tray. According to this technique, the patient consistently combined the internal and external details of each of the four figures. The patient was then offered to conduct such procedures at home. For this purpose, the pa-

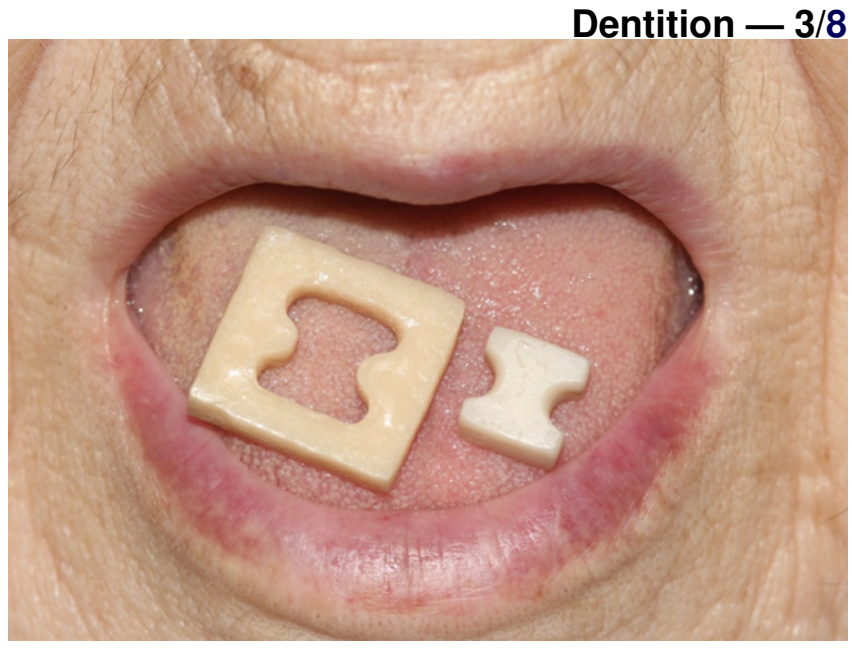

Figure 3. Details of the disassembled figure in the oral cavity of a 76-year-old patient $\mathrm{M}$.

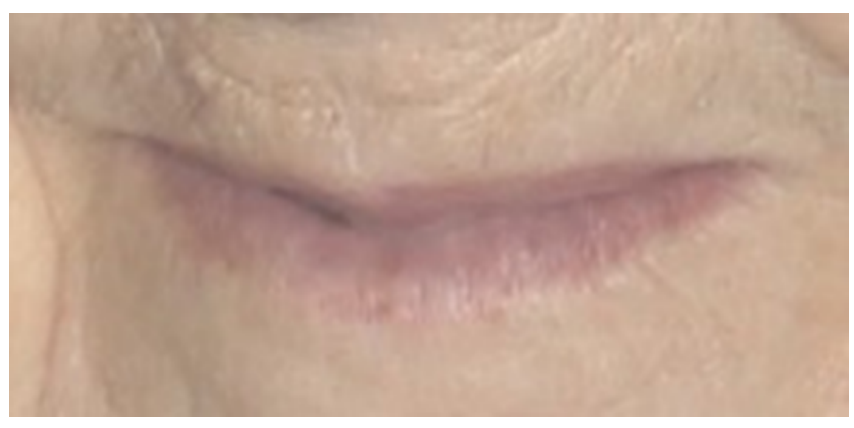

Figure 4. A 76-year-old patient M. is trying to collect the figure.

tient was given a set of standard samples. At home, the patient had to conduct MA-stimulation for 14 days three times a day for 15 minutes (to collect all figures of the standard set for several times) (Fig. 3, Fig. 4, Fig. 5).

At home, the patients handled with the set of standard samples according to the recommendations for maintenance on dentures after each session $[6,11]$. After the MA-stimulation course was completed and the patients returned the set of standard samples, all figures were sterilized by placing them into a $2 \%$ solution ID 212 for 60 minutes and autoclaving at $\mathrm{t}+134 \mathrm{C}^{\circ}[2]$. The method of oral stereognosis and the criteria for its evaluation were described in detail in our previous publication [9].

All statistical calculations were conducted with the use of built-in license data analysis package and descriptive statistics in Microsoft Excel 2007 
The Use of the Test for Oral Muscular Coordination Ability to Increase the Level of Adaptive Capacity of Oral Cavity Organs to Prosthodontic Treatment of Patients with Completely Absent

Dentition - 4/8

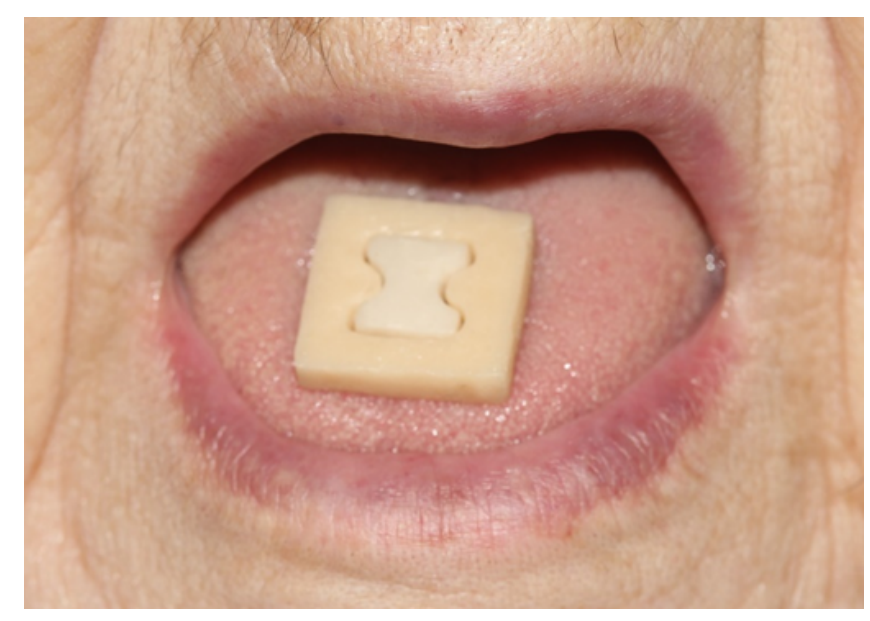

Figure 5. The assembled figure in the oral cavity of a 76-year-old patient M.

and Statistica 6.0. The clinical data obtained in the study were first verified by the type of their distribution according to the Kolmogorov-Smirnov test and the Lilliefors test. Since the absolute majority of these data conformed to Gaussian distribution, the standard error $(\mathrm{M} \pm \mathrm{m})$ was used to describe the central tendency, and parametric t-test (Student t-test) for dependent or independent samples was applied to assess the probability of the differences of the obtained results and the verification of the null hypothesis [5].

\section{Results and Discussion}

The results of the research of oral stereognosis before the prosthodontic treatment, in the course of treatment and after the prosthodontic treatment are presented in Tables 1 and 2. The results of the oral stereognosis study showed that the initial data (before the prosthodontic treatment) concerning the tactile sensitivity of the oral mucosa in patients with completely absent dentition (Groups I and II) were remarkably and significantly different from those of the control group. Thus, the average time of one sample determination increased by 2.4 times $(\mathrm{p}<0.001)$, and the percentage of the correctness of the samples determination decreased by $44.4 \%$ $(\mathrm{p}<0.001)$.

The dynamics of oral stereognosis in patients of Group II was marked by a significant decrease in the average time of one sample determination and an increase in the correctness of the samples determination after a fourteen-day MA-stimulation. The comparison of the average time of one sample determination before the onset of the prosthodontic treatment and after 14 days of MA-stimulation showed that this index decreased by $24.5 \%\left(\mathrm{p}_{1}<0.05\right)$. Meanwhile, the index of the samples determination correctness increased by $32.0 \%\left(\mathrm{p}_{1}<0.001\right)$. The results of oral stereognosis in Group II of patients in 1 month after the prosthodontic treatment were quite indicative. Thus, the average time of one sample determination in 1 month after the prosthodontic treatment in comparison with the observation period called "in 14 days" significantly decreased by $19.3 \%\left(\mathrm{p}_{2}<0.05\right)$, and the correctness of the samples determination significantly increased by $17.5 \%\left(\mathrm{p}_{2}<0.001\right)$. Thus, according to the estimation of the dynamics of the average time of one sample determination in Group II in 1 month after the prosthodontic treatment as compared to the period of observation "before the onset of the prosthodontic treatment", this index decreased by $39.0 \%\left(\mathrm{p}_{1}<0.001\right)$, and the accuracy of the correctness of the samples determination increased by $55.1 \%\left(\mathrm{p}_{1}<0.001\right)$ during this time.

A significant decrease in the average time of one sample determination and a significant increase in the correctness of the samples determination in 1 month after the prosthodontic treatment were observed in the course of the analysis of oral stereognosis indices obtained in different observation periods in Group I of patients. However, the average time of one sample determination decreased only by $14.7 \%\left(\mathrm{p}_{2}<0.05\right)$ as compared to the observation period called "in 14 days" or by $18.3 \%\left(\mathrm{p}_{1}<0.05\right)$ in comparison with the observation period "before the prosthodontic treatment", and the correctness of the samples determination increased by $24.5 \%$ $\left(\mathrm{p}_{2}<0.05\right)$ or by $31.5 \%\left(\mathrm{p}_{1}<0.05\right)$, respectively.

According to the results of oral stereognosis, continuation of the restoration of the oral mucosa tactile sensitivity was observed during the examination of patients in Group II 3 months after the prosthodontic treatment. In particular, the average time of one sample determination decreased 
The Use of the Test for Oral Muscular Coordination Ability to Increase the Level of Adaptive Capacity of Oral Cavity Organs to Prosthodontic Treatment of Patients with Completely Absent

Dentition - 5/8

Table 1. Dynamics of oral stereognosis indices (an average time of one sample determination (sec).

\begin{tabular}{l|c|c|c|c}
\hline $\begin{array}{l}\text { Periods of obser- } \\
\text { vation }\end{array}$ & $\begin{array}{c}\text { Before the } \\
\text { prosthodontic } \\
\text { treatment }\end{array}$ & $\begin{array}{c}\text { Before CRLD } \\
\text { retention (in 14 } \\
\text { days) }\end{array}$ & $\begin{array}{c}1 \text { month after the } \\
\text { prosthodontic } \\
\text { treatment }\end{array}$ & $\begin{array}{c}3 \text { months after the } \\
\text { prosthodontic } \\
\text { treatment }\end{array}$ \\
\hline $\begin{array}{l}\text { Group I (clinical } \\
\text { comparison) } \\
\text { (n=30) }\end{array}$ & $\begin{array}{c}36.58 \pm 1.44 \\
\mathrm{p}<0.001\end{array}$ & $\begin{array}{c}35.01 \pm 1.45 \\
\mathrm{p}_{1}>0.05\end{array}$ & $\begin{array}{c}29.88 \pm 1.44 \\
\mathrm{p}_{2}<0.05\end{array}$ & $\begin{array}{c}28.37 \pm 1.40 \\
\mathrm{p}_{3}>0.05\end{array}$ \\
\hline $\begin{array}{l}\text { Group II (the main } \\
\text { group) ( } \mathrm{n}=60)\end{array}$ & $\begin{array}{c}36.86 \pm 1.86 \\
\mathrm{p}<0.001\end{array}$ & $\begin{array}{c}27.84 \pm 1.52 \\
\mathrm{p}_{1}<0.001\end{array}$ & $\begin{array}{c}22.48 \pm 1.38 \\
\mathrm{p}_{2}<0.05\end{array}$ & $\begin{array}{c}18.57 \pm 1.25 \\
\mathrm{p}_{3}<0.05\end{array}$ \\
\hline $\begin{array}{l}\text { Control group } \\
\text { (n=30) }\end{array}$ & \multicolumn{2}{|c}{$15.56 \pm 1.08$} & \\
\hline
\end{tabular}

Note: the probability of index difference in comparison with -

$\mathrm{p}$ - control group;

$\mathrm{p}_{1}$ - before the treatment;

$\mathrm{p}_{2}-$ in 14 days;

$\mathrm{p}_{3}$ - in 1 month.

Table 2. Dynamics of oral stereognosis indices (the correctness of samples determination (\%).

\begin{tabular}{l|c|c|c|c}
\hline $\begin{array}{l}\text { Periods of obser- } \\
\text { vation }\end{array}$ & $\begin{array}{c}\text { Before the } \\
\text { prosthodontic } \\
\text { treatment }\end{array}$ & $\begin{array}{c}\text { Before CRLD } \\
\text { retention (in 14 } \\
\text { days) }\end{array}$ & $\begin{array}{c}1 \text { month after the } \\
\text { prosthodontic } \\
\text { treatment }\end{array}$ & $\begin{array}{c}3 \text { months after the } \\
\text { prosthodontic } \\
\text { treatment }\end{array}$ \\
\hline $\begin{array}{l}\text { Group I (clinical } \\
\text { comparison) } \\
(\mathrm{n}=30)\end{array}$ & $\begin{array}{c}51.67 \pm 4.78 \\
\mathrm{p}<0.001\end{array}$ & $\begin{array}{c}54.58 \pm 4.62 \\
\mathrm{p}_{1}>0.05\end{array}$ & $\begin{array}{c}67.92 \pm 4.03 \\
\mathrm{p}_{2}<0.05\end{array}$ & $\begin{array}{c}72.08 \pm 3.94 \\
\mathrm{p}_{3}>0.05\end{array}$ \\
\hline $\begin{array}{l}\text { Group II (the main } \\
\text { group) (n=60) }\end{array}$ & $\begin{array}{c}51.46 \pm 3.35 \\
\mathrm{p}<0.001\end{array}$ & $\begin{array}{c}67.92 \pm 2.64 \\
\mathrm{p}_{1}<0.001\end{array}$ & $\begin{array}{c}79.79 \pm 2.15 \\
\mathrm{p}_{2}<0.001\end{array}$ & $\begin{array}{c}88.13 \pm 1.54 \\
\mathrm{p}_{3}<0.01\end{array}$ \\
\hline $\begin{array}{l}\text { Control group } \\
\text { (n=30) }\end{array}$ & \multicolumn{2}{|c}{$92.92 \pm 1.52$} & \\
\hline
\end{tabular}

Note: the probability of index difference in comparison with -

$\mathrm{p}$ - control group;

$\mathrm{p}_{1}$ - before the treatment;

$\mathrm{p}_{2}$ - in 14 days;

$\mathrm{p}_{3}$ - in 1 month.

by $17.4 \%\left(\mathrm{p}_{3}<0.05\right)$ as compared to the observation period "1 month after the prosthodontic treatment", and the correctness of the samples determination increased by $10.5 \%\left(\mathrm{p}_{3}<0.01\right)$ during this time. According to the comparison of oral stereognosis indices in patients of Group II during the entire period of the observation (from the initiation of the prosthodontic treatment to the observation period "3 months after the prosthodontic treatment"), the average time of one sample determination decreased by $49.6 \%\left(\mathrm{p}_{1}<0.001\right)$ and the correctness of the samples determination increase by $71.3 \%$ $\left(\mathrm{p}_{1}<0.001\right)$. It should also be noted that both indices of oral stereognosis in patients of Group II approximated to similar indices in individuals of the control group 3 months after the prosthodontic treatment.

However, the recovery of tactile sensitivity of 
The Use of the Test for Oral Muscular Coordination Ability to Increase the Level of Adaptive Capacity of Oral Cavity Organs to Prosthodontic Treatment of Patients with Completely Absent

Dentition - 6/8

the oral mucosa in patients of Group I was very slow in 1 month of the observation and the indices of oral stereognosis slightly changed positively, but the probability of the difference in indices was not achieved $\left(\mathrm{p}_{3}>0.05\right)$. Eventually, the average time of one sample determination in Group I of patients decreased by $22.5 \%\left(\mathrm{p}_{1}<0.001\right)$ for the entire period of the observation (from the initiation of the prosthodontic treatment to the observation period "3 months after the prosthodontic treatment") and the correctness of the samples determination increased by $39.5 \%\left(\mathrm{p}_{1}<0.001\right)$.

Nowadays, oral stereognosis is more often used as one of the indicators of the level of adaptation to CRLD [19, 12, 13, 14, 15]. Improvement of the oral mucosa sensitivity as a result of CRLD use was observed by D. Dahiya and co-authors in their studies [12]. V. Singh and co-authors believed the coverage of the mucous membrane of the palate with CRLD not to reduce the tactile sensitivity of the oral mucosa [19]. However, M. Dalaya argued that the better the indices of oral stereognosis, the worse the processes of adaptation to CRLD and the less the patient's satisfaction from its use [13]. The results of our research in Group I of patients showed that the adaptation processes improved during the use, especially during 1 month after the prosthodontic treatment.

R. Rossetti and co-authors studied the entire literature on oral stereognosis and the treatment of completely absent dentition since 1944. One of the authors' conclusions stated that oral stereognosis could be improved by training [18]. Professor R. Marxkors believes that one of the methods of such training is the phased CRLD manufacturing, especially during their repeated restoration. In the course of phased CRLD manufacturing, oral tissues gradually adapt to the results of the prosthodontic treatment, in particular the imbalance of masticatory muscles is corrected [7]. Our research on the use of MA-stimulation as a means of restoration of not only oral mucosa sensitivity but also the coordination of masticatory muscles also proved that training processes were particularly important for increase in the level of adaptability to CRLD use.

\section{Conclusions}

The use of MA-stimulation during 14 days in patients with completely absence dentition in the course of the prosthodontic treatment increased the adaptability of the oral cavity organs to CRLD use. This was evidenced by positive significant changes in oral stereognosis after MA-stimulation: 1) before CRLD retention; 2) 1 month after the prosthodontic treatment; 3$) 3$ months after the prosthodontic treatment. The use of CRLD in patients with completely absent dentition without preliminary MA-stimulation contributed to positive significant changes in oral stereognosis indices only 1 month after the prosthodontic treatment.

\section{Prospects of Further Researches}

Prospects for further research involve the study of MA-stimulation importance as a means of increasing the level of the oral organs adaptability to the prosthodontic treatment of patients with completely absent dentition based on the characteristics of surface electromyography musculus masseter and musculus temporalis. The study of oral stereognosis in patients with completely absent dentition who should recognize standard figures not only by their form but also by their size is also promising [15].

\section{References}

[1] Aryeva GT, Aryev AL. Gerontostomatologiya - obyektivnaya realnost. Klinicheskaya gerontologiya. 2008;7:3-8.

[2] Sokolova MP, Stoyan OYu, Mayer YuH et al. Aseptyka ta antyseptyka $\mathrm{v}$ ambulatornykh i statsionarnykh stomatolohichnykh zakladakh. Navchalnyi posibnyk. Kharkiv - Poltava Odesa: Tornado; c2006.114p.

[3] Barkan IYu. Ortopedicheskaya stomatologicheskaya reabilitatsiya bolnykh pozhilogo i starcheskogo vozrasta, polzuyushchikhsya syemnymi protezami, s uchetom ikh kharakterologicheskikh osobennostey i stereognoziyi. 
The Use of the Test for Oral Muscular Coordination Ability to Increase the Level of Adaptive Capacity of Oral Cavity Organs to Prosthodontic Treatment of Patients with Completely Absent

Vserossiyskaya molodezhnaya nauchnaya konferentsiya "Novyye materialy i tekhnologiyi: sostoyaniye voprosa i perspektivy razvitiya"; 2014 24-26 iyunya; Saratov.

[4] Vatamaniuk MM, Belikov OB. Clinical and anthropometric analysis of anatomical and physiological condition in geriatric patients with total tooth loss. Bukovynskyi medychnyi visnyk. 2014;18,4(72):228-231. [published in Ukrainian]

[5] Detsyk OZ. Metodychni pidkhody do uzahalnennia rezultativ naukovykh doslidzhen. Galic'kij likars'kij visnik. 2011;18(2):5-8.

[6] Kak pravilno ukhazhivat za zubnymi protezami. May 23, 2014. Available from: https://infmedserv.ru/stati/kak-pravilnouhazhivat-za-zubnymi-protezami.

[7] Marxkors R. Syemnyye stomatologicheskiye restavratsiyi. Moscow: Informatsionnoye agenstvo "Newdent"; c2006. 315 p.

[8] Baran IYu, Struyev IV, Usov GM et al. Oralnaya stereognoziya i sposobnost k tonkoy koordinatsiyi zhevatelnoy muskulatury u patsiyentov pozhilogo i starcheskogo vozrasta s pogranichnymi psikhicheskimi rasstroystvami. Stomatologiya dlya vsekh. 2009;4:42-44.

[9] Sarapuk VI, Rozhko MM. Oral stereognosis in patients with completely edentulous jaws. Galician Medical Journal. 2018;25(2):61-63. DOI: https://doi.org/10.21802/ gmj.2018.2.11

[10] Tsisar MP, Matveyenko RYu, Smolich YuI. Osobennosti adaptatsionnogo perioda, pravila polzovaniya i ukhoda za polnymi syemnymi plastinochnymi protezami (rekomendatsiyi dlya vrachey i patsiyentov). Zubnoye protezirovaniye. 2010;1:8-12.

[11] Yanishen IV, Sukhan MV, Pereshyvailova IO. Vyvchennia bakterytsydnoii aktyvnosti tabletok $\ll$ Fittydent $\gg$ dlia ochyshchennia znimnykh konstruktsiy proteziv v klinitsi ortopedychnoii stomatolohiii. Zbirnyk materialiv mizhnarodnoii naukovo-praktychnoii konferentsiii "Medychna nauka ta praktyka: aktualni pytannia vzayemodiii"; 2015 Sept 4-5; Kyiv. 2015. p. 48-52.

[12] Dahiya D, Thukzal M, Rethwa R. Oral stereognostic ability - sensory perception in complete denture patients. International Journal of Enhanced Research in Medicines Dental Care, ISSN. 2016;3:69.

[13] Dalaya MV. A study of oral stereognostic proficiency in dentulous and edentulous persons. Journal of Clinical and Diagnostic Research. 2014;8:Z01Z06. DOI: https://doi .org/ $10.7860 / \mathrm{JCDR} / 2014 / 9212.4341$ [PMid:24995263 PMCid:PMC4080084]

[14] Ikbal LK, Kerem K, Ravza E et al. Evaluation of oral stereognosis in relation to tactile ability and patient satisfaction. Journal of Oral Implantology. 2017;43(6):468475. DOI: https://doi.org/10. 1563/aaid-joi-D-17-00130

[PMid:29064764]

[15] Meenakshi S, Gujjari AK, Thippeswamy MV et al. Evaluation of oral stereognostic ability after rehabilitating patients with complete dentures: in vivo study. Journal of Indian Prosthodontic Society. 2014;14(4):363-368. DOI: https://doi.org/10.1007/ s13191-013-0333-z [PMid:25489159 PMCid:PMC4257932]

[16] Landt H, Fransson B. Oral ability to recognize forms and oral muscular coordination ability in dentulous young and elderly adults. Journal of Oral Rehabilitation. 1975;2(2):125-138. DOI: https://doi.org/10.1111/ j.1365-2842.1975.tb01523.x [PMid:1056442]

[17] Landt M, Fransson B, Alin L. Oral recognition of forms and oral muscular coordination ability. A longitudinal study in young adults. Journal 
The Use of the Test for Oral Muscular Coordination Ability to Increase the Level of Adaptive Capacity of Oral Cavity Organs to Prosthodontic Treatment of Patients with Completely Absent

Dentition - 8/8

of Oral Rehabilitation. 1979;6:279-290.

DOI: https://doi.org/10.1111/

j.1365-2842.1979.tb01506.x

[PMid:287773]

[18] Rossetti P, Bonachela W, Nunes L. Oral stereognosis related to the use of complete dentures: a literature review. International Journal of Medical Sciences. 2004;2:5760. DOI: https://doi.org/10.5466/ ijoms.2.57

[19] Singh V, Matto K. Oral stereognosis pattern in patients with dental prosthesis in the elderly population. International Journal of Clinical and Experimental Physiology. 2014;1:211215. DOI: https : / / doi .org/10.4103/ 2348-8093.143490

Received: 2019-09-10

Revised: 2019-10-21

Accepted: 2019-10-21 